\section{Oversiktlig innføring i etisk teori og praksis}

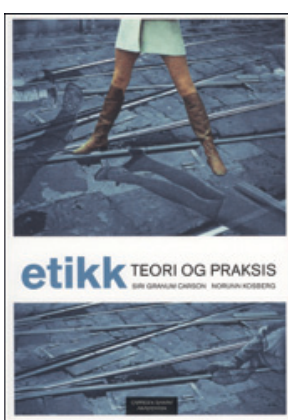

Siri Granum Carson, Norunn Korsberg Etikk

Teori og praksis. 208 s. Oslo: Cappelen

Damm Akademisk, 2011. Pris NOK 298

ISBN 978-82-02-34084-1

Forfatterne er to filosofer med anvendt etikk som spesialfelt. I forlagets omtale hevder man at boken er godt egnet som innføringsbok i etikk for ex. phil.- og ex. fac-studenter, men at den også er relevant for studenter i helsefag og andre fag hvor etikkspørsmål står sentralt, og for alle som ønsker en lett tilgjengelig og praktisk orientert innføring i etikk.

Det hele åpner med en diskusjon av hva etikk og moral er. Deretter tar forfatterne for seg ulike sentrale etiske teorier: utilitarisme, Kants deontologiske etikk, dydsetikk og rettighetsetikk. I de videre kapitlene drøfter de diskursetikk, nærhetsetikk, livssyn og menneskesyn, etikk i praksis og etisk navigasjon. Med utgangspunkt i de opprinnelige etiske teoriene drøfter de nyere bidrag og styrker og svakheter ved de ulike perspektivene. Teoriene settes opp mot hverandre, og forskjellene klargjøres.

Etter hvert kapittel stiller forfatterne utfordrende spørsmål som kan drøftes av leseren. I alle kapitlene illustreres de etiske dilemmaene med dagsaktuelle hendelser og temaer: Amelie-saken, homofili og kunstig befruktning, Harald Eias hjernevaskprogram, Knausgårds selvbiografiske romanprosjekt osv. Nye etiske problemstillinger i cyberspace («nettikette») blir også interessant omtalt.

Etter min oppfatning er boken det den gir seg ut for å være: en introduksjon til etisk teori og praksis. Språket er presist, og det er lett å lese. Forfatterne gaper over mye - noe som både er en styrke og en svakhet.

Leseren blir kjent med hovedlinjene i etisk teori, nyere oppdateringer og anvendt etikk. Samtidig blir behandlingen av de ulike temaene med nødvendighet nokså summarisk preget og med lite rom for dypdykk. Det er interessant at forfatterne presenterer nyere etikkteori som ofte handler om nyansering av de gamle klassiske teoriene. Enkelte temaer blir unødvendig gjentatt, for eksempel om menneskerettighetene, og enkelte feil finnes, helsedirektøren heter for eksempel ikke Bjørn Inge Hansen, og teologisk og teleologisk etikk blandes. Det er heller ikke riktig at Legeforeningens etiske kodeks er i stadig endring. De praktiske dagsaktuelle eksemplene gjør stoffet interessant og ja, nettopp - etisk teori og praksis aktuelt.

Boken anbefales for dem som ønsker en oversiktlig og kortfattet innføring i etisk teori og praksis. Både medisinsk etikk og profesjonsetikk, bl.a. legeetikk, har sitt utgangspunkt i allmenn etisk teori, men blir lite omtalt. Hvis leserens behov går i retning av fordypning i disse temaene, må man gå til andre tekster.

\section{Nyttig for oss alle}

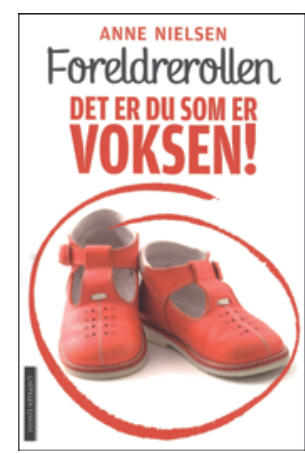

\section{Anne Nielsen}

\section{Foreldrerollen}

Det er du som er voksen! 280 s, ill.

Oslo: Cappelen Damm, 2011. Pris NOK 329

ISBN 978-82-02-33791-9

Forfatteren er utdannet førskolelærer og samtaleterapeut. Her henvender hun seg til foreldre, besteforeldre, ansatte i førskole og skole, helsesøstre og leger - kort sagt alle som har med barn å gjøre. Basert på en rekke personlige og profesjonelle erfaringer, og med støtte i litteratur og ulike undersøkelser, beskriver hun sitt ønske: «Å bidra til at flest mulig barn får mulighet til å utvikle og bruke sine talenter og evner i størst mulig grad, samtidig som de lærer å leve i harmoni med andre og finner et fellesskap hvor de hører til (...) ikke et liv uten konflikt eller motgang, siden motgang er livets læremester, men et liv som gir dem motstandskraft til å tåle livets opp- og nedturer.»

Boken er delt i tre hoveddeler med underkapitler og sammendrag: del 1 Tidsånden: Hva skjer nå og hvorfor?, del 2 Medisinen: Kunnskap om barns utvikling og del 3 Veien videre. Det er også et tillegg med ytterligere erfaringer, litteraturreferanser og stikkordregister.

Et utgangspunkt er spørsmålet om hvorfor dagens foreldre er så ettergivende og usikre. Dette belyses historisk og med tallrike gode eksempler, bl.a. hvorledes dagens curlingforeldre, ofte som følge av tidligere tiders autoritære oppdragelse, møter barna med overbeskyttelse og sammenblanding av service og kjærlighet. De kan ønske seg trygge og fornøyde barn, men får i stedet små prinser og prinsesser som ikke har lært å ta hensyn til andre.

$\AA$ ta barn på alvor, å forstå og respektere deres behov og reaksjoner og samtidig være en tydelig autoritet kan være vanskelig, men nødvendig. Her belyses utfordringer og godt og dårlig samspill med barna med tallrike gode eksempler, også hentet fra dagsaktuelle TV-programmer og avisinnlegg. Det er også kloke refleksjoner om maskuline og feminine særtrekk og utfordringer om likestilling og omsorg for barn.

Kort sagt: Forfatteren har oppnådd sitt mål. Dette er en bok om hvordan vi i omgang med barn, spesielt i alderen 1-12 år, som trygge voksne med sunn selvfølelse og autoritet, men uten bruk av makt, kan bidra til å gi dem en trygg selvfølelse og god funksjon både borte og hjemme.

Jeg gir boken min varmeste anbefaling. Å oppdra barn krever handlekraft og vilje til å stå oppreist selv når barna ikke liker det vi bestemmer. Ta foreldremakten tilbake - og bli en trygg voksen som barna kan stole på! 